\title{
Pengaruh Penerapan Standar Komunikasi Defisit Perawatan Diri terhadap Kemandirian Merawat Diri pada Pasien Skizofrenia di Ruang Rawat Inap Delta Rumah Sakit Jiwa Daerah Provinsi Jambi
}

\author{
Rd. Hari Periza $W^{1}$, Rahmi Dwi Yanti ${ }^{2}$, Vevi Suryenti Putri ${ }^{3}$ \\ ${ }^{1,2,3}$ Program Studi S1 Keperawatan STIKES Baiturrahim Jambi \\ Email : radenhari95@gmail.com
}

Published: 06/03/2021

\begin{abstract}
Schizophrenic is a disease that affects the brain and causes strange, disturbed thought, perception, emotion, movement, and behavior. These case made patient experiencing significant self-care deficit, causing patients did not pay attention to hygiene. The nursing tread to deal the patient with schizophrenic is the application of self-care deficit communication standard. This study aimed to indicated the influence of applying self-care deficit communication strategies to self-care independence in schizophrenic patient. This study used quantitative research by using pre preexperiment design, with one group pretest posttest was used. The number of samples were 20 persons. This study used purposive sampling technique. It was conducted on January 1th - 15th 2020. The data were collected by an instrument in the form of observation sheets. It were analyzed by the Wilcoxon test. The findings, The average self-care independence before implementing the self-care communication deficit standard with an average value (3.00) to (4.00) after the application of communication standards is given. There is a difference in the application of the self-care deficit communication standard with a P-value $=0.001$.
\end{abstract}

Keywords: application of DPD communication standards, independence, schizophrenic

\begin{abstract}
Abstrak
Skizofrenia adalah suatu penyakit yang memengaruhi otak dan menyebabkan timbulnya pikiran, persepsi, emosi, gerakan, dan perilaku yang aneh dan terganggu.Hal ini menyebabkan pasien mengalami defisit perawatan diri yang signifikan, sehingga menyebabkan pasien tidak memperhatikan kebutuhan hygiene. Tindakan keperawatan untuk menangani pasien dengan skizofrenia yaitu penerapan standar komunikasi defisit perawatan diri. Tujuan penelitian yaitu untuk mengetahui apakah ada pengaruh penerapan strategi komunikasi defisit perawatan diri terhadap kemandirian merawat diri pada pasien skizofrenia. Penelitian ini merupakan penelitian kuantitatif dengan metode penelitian pre eksperiment dengan desain penelitian yang digunakan adalah one grouppretestposttest. Jumlah sampel dalam penelitian sebanyak 20 orang. Tekhnik pengambilan sampel dengan menggunakan tekhnik purposive sampling.Penelitian telah dilakukan pada tanggal 1 Januari - 15 Januari 2020, data dikumpulkan menggunakan instrument berupa lembar observasi. Data dianalisis dengan menggunakan uji Wilcoxon. Rata-rata kemandirian merawat dirisebelum dilakukan penerapan standar komunikasi defisit perawatan diri dengan nilai rata-rata(3,00) menjadi $(4,00)$ sesudah diberikan penerapan standar komunikasi. Terdapat perbedaan penerapan standar komunikasi defisit perawatan diri dengan $P$-value $=0,001<0,05$. Hasil penelitian ini dapat disimpulkan ada pengaruh penerapan standar komunikasi defisit perawatan diri terhadap kemandirian merawat diri pada pasien skizofrenia.
\end{abstract}

Kata Kunci : kemandirian, penerapan standar komunikasi DPD, skizofrenia

\section{PENDAHULUAN}

Skizofrenia adalah suatu penyakit yang memengaruhi otak dan menyebabkan timbulnya pikiran, persepsi, emosi, gerakan, dan perilaku yang aneh dan terganggu. Skizofrenia tidak dapat didefinisikan sebagai penyakit tersendiri, melainkan diduga sebagai sindrom atau proses penyakit yang mencakup berbagai jenis dengan gejala seperti jenis kanker. 
Penyakit ini ditakuti sebagai gangguan jiwa yang berbahaya dan tidak dapat dikontrol, dan mereka yang terdiagnosis penyakit ini digambarkan sebagai individu yang tidak mengalami masalah emosional atau psikologis yang terkendali (Videbeck, 2015).

Menurut data Wolrd Health Organization (WHO), terdapat sekitar 35 juta orang terkena depresi, 60 juta orang terkena bipolar, 21 juta terkena skizofrenia, serta 47,5 juta terkena dimensia. Di Indonesia, dengan berbagai faktor biologis, psikologis, dan sosial dengan keanekaragaman penduduk, maka jumlah kasus gangguan jiwa terus bertambah yang berdampak pada penambahan beban negara dan penurunan produktivitas manusia untuk jangka panjang (WHO) ( 2016 ).

Berdasarkan data Riset Kesehatan Dasar ( RISKESDAS, 2018 ) gangguan jiwa di Indonesia adalah $7 \%$ permil dari populasi penduduk dan Provinsi Jambi merupakan Provinsi dengan urutan sejajar dengan angka Indonesia, yaitu $7 \%$ permil dari penduduk, Provinsi dengan angka kejadian tertinggi adalah Provinsi Bali yaitu 10,5\% dan Provinsi dengan angka kejadian terendah adalah Provinsi Kepulauan Riau yaitu 3\%. Sementara cakupan jiwa skizofrenia dari $100 \%$ sebanyak $84,9 \%$ berobat dan $15,51 \%$ tidak berobat dengan alasan merasa sudah sehat sebanyak $36,1 \%$.

Berdasarkan data dari Rumah Sakit Jiwa Daerah Provinsi Jambi dari tahun 2017, 2018 dan 2019, didapatkan penderita skizofrenia yang melakukan rawat inap di Rumah Sakit Jiwa Daerah Provinsi Jambi pada tahun 2017 sebanyak 1589 orang, tahun 2018 sebanyak 1500 orang dan ditahun 2019 sebanyak 1524 orang.

Tidak ada penampilan atau perilaku yang khas pada pasien skizofrenia. Beberapa bahkan dapat berpenampilan dan berperilaku "normal". Mungkin mereka tampak berpreokupasi terhadap kesehatan, penampilan badan, agama atau minatnya. Pasien dengan skizofrenia kronis cenderung menelantarkan penampilannya. Kerapian dan hygiene pribadi juga terabaikan. Mereka juga cenderung menarik diri secara sosial (Maramis, 2009).

Secara umum, klien skizofrenia akan mengalami beberapa maslaah keperawatan. Pasien skizofrenia mengalami penurunan pada aktivitas sehari-hari karena kehilangan motivasi dan apatis berarti kehilangan energi dan minat dalam hidup. Keadaan apatis pada skizofrenia menyebabkan terganggunya aktifitas rutin sehari-hari seperti mandi, menyisir rambut, gosok gigi dan tidak mempedulikan kerapian diri atau berpakaian/berdandan secara eksentrik (Ibrahim, 2010).

Klien skizofrenia kehilangan motivasi dan minat hidup yang membuat klien menjadi orang malas, karena klien skizofrenia hanya memilki energi yang sedikit, mereka tidak biasa melakukan halhal yang lain selain tidur dan makan. Hal ini menyebabkan pasien mengalami defisit perawatan diri yang signifikan, sehingga menyebabkan pasien tidak memperhatikan kebutuhan hygiene, makan, tidak mempedulikan kerapian diri atau berpakaian, berdandan, dan toileting. Penurunan kemampuan perawatan diri dapat dipicu oleh adanya peningkatan kecemasan yang timbul akibat pikiran waham, halusinasi, perilaku kekerasan. Selain itu, hambatan hubungan sosial dapat memperburuk kemampuan perawatan diri (Yosep, 2010).

Defisit perawatan diri adalah salah satu gejala yang dialami oleh pasien skizofrenia sebagai salah satu gejala negatif. Tidak ada psikofarmaka yang dapat mengatasi defisit perawatan diri selain melatih pasien mengatasi ketidakmampuan atau ketidakmauan melakukan perawatan diri. Klien mungkin mengalami kemunduran kemampuan berpikir sehingga mengalami kemunduran perkembangan. Perilaku pasien menjadi seperti masa kanak-kanak yang bergantung kepada orang lain (Keliat, 2014). 
Dampak dari defisit perawatan diri secara fisik yaitu: gangguan integritas kulit, gangguan membrane mukosa mulut, serta gangguan fisik pada kuku, juga berdampak pada masalah psikososial seperti gangguan kebutuhan rasa nyaman, kebutuhan dicintai dan mencintai, kebutuhan harga diri, aktualisasi diri, dan gangguan interaksi sosial. Lebih jauh lagi masalah tersebut bisa menularkan berbagai macam penyakit kepada penghuni lain dan juga tenaga kesehatan (Direja, 2011).

Self-care (perawatan diri) merupakan suatu kontribusi berkelanjutan orang dewasa bagi eksistensinya, kesehatannya dan kesejahteraannya. Self-care ini menggambarkan dan menjelaskan manfaat perawatan diri guna mempertahankan hidup, kesehatan, dan kesejahteraannya. Jika dilakukan secara efektif, upaya perawatan diri dapat memberi kontribusi bagi integritas struktural fungsi dan perkembangan manusia (Budiono, 2015).

Kemandirian adalah suatu sikap yang memungkinkan seseorang untuk bertindak bebas, melakukan sesuatu atas dorongan sendiri untuk kebutuhannya sendiri tanpa bantuan orang lain. Kemandirian adalah sikap yang menghendaki seseorang untuk bertindak bebas. Artinya dapat melakukan sesuatu atas dorongan sendiri sesuai dengan hak dan kewajiban sebagai seorang manusia, yaitu harus mampu menyelesaikan masalahnya sendiri (Hanifah, 2014).

Merawat diri adalah salah satu kemampuan dasar manusia dalam memenuhi kebutuhannya guna mempertahankan kehidupannya, kesehatan, dan kesejahteraan sesuai dengan kondisi kesehatannya. Pasien dinyatakan tergangu kesehatan dan kesejahteraan sesuai dengan kondisi kesehatannya dan terganggu keperawatan dirinya jika tidak dapat melakukan perawatan diri (Direja, 2011).

Pada pasien defisit perawatan diri ada empat Standar Pelaksanaan Komunikasi (SP). Melatih kebersihan diri, melatih makan dan minum, melatih BAB dan BAK, dan melatih kebersihan dan kerapihan lingkungan. Pada SP 1, Melatih kebersihan diri : mandi, keramas, sikat gigi, berpakaian, berhias dan gunting kuku. Pada SP 2, melatih makan dan minum: diskusikan gunanya makan dan minum yang baik dan teratur, diskusikan alat tempat makan dan minum, diskusikan kebutuhan makan dan minum yang baik: cuci tangan, berdo'a, makan dimeja makan. SP 3, Melatih BAB dan BAK: diskusikan gunannya $\mathrm{BAB}$ dan $\mathrm{BAK}$, diskusikan tempatm cara menggunakan, cara membersihkan tempat dan cara membersihkan diri, latih $\mathrm{BAB}$ dan $\mathrm{BAK}$ yang baik. SP 4 melatih kebersihan dan kerapihan lingkungan rumah: membersihkan dan Merapikan lingkungan yaitu kamar, tidur, ruang makan, dapur, kamar mandi (Keliat, 2019).

$$
\text { Dalam strategi pelaksanaan }
$$

komunikasi asuhan keperawatan defisit perawatan diri, di ajarkan kemampuan untuk merawat diri. Setiap kemampuan yang diajarkan dimasukkan dalam jadwal harian untuk kemudian dilatih. Pelaksanaan jadwal harian dalam asuhan keperawatan defisit perawatan diri ini bermanfaat untuk meningkatkan kemandirian pasien dalam merawat diri. Hal ini dapat dilihat pada Peneliti Pinedendi, dengan judul "Pengaruh Penerapan Asuhan Keperawatan Defisit Perawatan Diri Terhadap Kemandirian Personal Hygiene Pada Pasien di RSJ. Prof. V. Ratumbuysang Manado Tahun 2016". Hasil Penelitian adanya pengaruh penerapan asuhan keperawatan devisit perawatan diri terhadap kemandirian personalhygiene pada pasien di Ruangan Katrili dan Alabadiri RSJ. Prof. Dr. V. L. Ratumbuysang Manado $(p=0,003<a ́=0,05)$.

Peneliti Hastuti dengan judul "Pengaruh Pelaksanaan Jadwal Harian Perawatan Diri Terhadap Tingkat Kemandirian Merawat Diri Pada Pasien Skizofrenia di RSJD DR. RM Soedjarwadi Provinsi Jawa Tengah Tahun 2018". Hasil penelitian: Berdasarkan uji statistik dengan 
paired t-test didapatkan nilai $\rho=0,000$ $(\alpha<0,05)$ maka Ha diterima dan Ho ditolak. Nilai mean sebelum pelaksanaan jadwal adalah 15,65 dan setelah dilakukan jadwal nilai mean kemandirian adalah 6,45 , menunjukkan adanya pengaruh pelaksanaan jadwal harian perawatan diri terhadap tingkat kemandirian merawat diri pada pasien skizofrenia di RSJD Dr. RM Soedjarwadi Provinsi Jawa Tengah.

Berdasarkan jumlah diagnosa keperawatan terbanyak pasien skizofrenia rawat inap di Rumah Sakit Jiwa Provinsi Jambi Pada tahun 2019 tampak bahwa diagnosa keperawatan Halusinasi terbanyak pertama dengan jumlah 5419 kasus dan terbanyak di ruang Alpha, terbanyak ke 2 Waham dengan jumlah 204 kasus dan terbanyak di ruang Alpha dengan jumlah 89 kasus, dan terbanyak ke 3 Defisit Perawatan Diri dengan jumlah 184 kasus dan terbanyak di ruang Shinta dengan jumlah 102 kasus dan ruang Pega dengan 77 kasus.

Hasil survey awal yang dilakukan pada tanggal 06 Oktober 2019, Dari 10 klien, pada saat diajak berkomunikasi 8 mengatakan pernah diajarkan dengan perawat ruangan bagaimana cara mandi yang benar, , cara berdandan, cara menyiapkan makanan, merapikan makanan, dan cara BAB dan BAK yang baik, sedangkan 2 klien pada saat diajak berkomunikasi, klien banyak diam dan kurang fokus.

Hasil observasi menunjukkan bahwa 7 dari 10 klien terkadang masih menerima bantuan perawat ketika menjalani aktifitas perawatan diri dan masih diingatkan seperti makan, mandi, berpakaian, berhias, makan dan minum, toileting harus diarahkan dan diingatkan. Sedangkan 3 klien lainnya dapat melakukan aktivitas sehari-hari sendiri tanpa bantuan perawat seperti makan, mandi, berpakaian, berhias, makan, minum, toileting. Tetapi semua klien tetap harus di pantau dalam kegiatan dan kebutuhan sehari-harinya.
Berdasarkan uraian diatas, maka peneliti tertarik untuk melakukan penelitian mengenai "Pengaruh Penerapan Standar Komunikasi Defisit Perawatan Diri Terhadap Kemandirian Merawat Diri Pada Pasien Skizofrenia Di Ruang Rawat Inap Delta Di Rumah Sakit Jiwa Daerah Provinsi Jambi".

\section{METODE PENELITIAN}

Penelitian ini merupakan penelitian kuantitatif dengan pendekatan metode Pre Exsperiment dengan desain One Group dengan rancangan Pretest-Posttest bertujuan untuk mengetahui pengaruh penerapan standar komunikasi defisit perawatan diri terhadap kemandirian merawat diri pada pasien skizofrenia.

Instrumen penelitian yang digunakan adalah dengan menggunakan lembar pengkajian Ideks Kemandiran Katz. Komponen yang dinilai adalah dengan menggunakan 5 indikator dari Indekz Kemandirian Katz yang sudah di modifikasi. Yang terdiri dari mandi, berpakaian, ke kamar kecil, kontinen dan makan. Penelitian telah dilakukan pada tanggal 1 Januari - 15 Januari 2020. Populasi dalam penelitian ini sebanyak 184 responden dan sampel dalam penelitian ini adalaj 20 responden. Sampel yang dipilih merupakan sampel yang telah memenuhi kriteria inklusi. Metode pengambilan sampel dengan cara Purposive Sampling. Pengumpulan data dilakukan menggunakan instrument berupa lembar observasi dan metode analisa data univariat dan bivariat menggunakan uji Wilcoxon.

\section{HASIL DAN PEMBAHASAN}

Hasil penelitian dengan 20 responden tentang pengaruh penerapan standar komunikasi defisit perawatan diri terhadap kemandirian merawat diri pada pasien skizofrenia di ruang rawat inap Delta Rumah Sakit Jiwa Daerah Provinsi Jambi. Adapun hasil yang diperoleh adalah sebagai berikut. 
Gambaran karakteristik responden berdasarkan umur: dewasa awal berjumlah 7 orang ( $35 \%)$, Dewasa akhir 8 orang ( $40 \%$ ), Lansia Awal 5 orang ( $25 \%$ ), Berdasarkan hasil penelitian, diketahui bahwa dari 20 responden berjenis kelamin laki-laki 20 orang (100\%). $100 \%$ responden pendidikan akhir SD.

Gambaran Kemandirian Merawat Diri Pada Pasien Skizofrenia Di Ruang Rawat Inap Delta Rumah Sakit Jiwa Daerah Provinsi Jambi Sebelum Dilakukan Penerapan Standar komunikasi Defisit Perawatan Diri. Berdasarkan hasil dapat didapatkan dari 20 responden terhadap kemandirian merawat diri pada pasien skizofrenia di ruang rawat inap delta rumah sakit jiwa daerah provinsi jambi sebelum dilakukan penerapan standar komunikasi defisit perawatan diri dengan nilai mean (rata-rata) 3,00, dengan standar deviasi 0,649 sebelum dilakukan penerapan standar komunikasi defisit perawatan diri, dengan nilai minimum 2 dan maksimum 4. Hasil kuesioner yang didapatkan dengan menggunakan cara ukur observasi dan alat ukur lembar observasi adalah sebagian responden memiliki tingkat kemandirian merawat diri dalam kategori kurang.

Gambaran Kemandirian Merawat Diri Pada Pasien Skizofrenia Di Ruang Rawat Inap Delta Rumah Sakit Jiwa Daerah Provinsi Jambi Setelah Dilakukan Penerapan Standar komunikasi Defisit Perawatan Diri. Berdasarkan hasil didapatkan dari 20 responden terhadap kemandirian merawat diri pada pasien skizofrenia di ruang rawat inap delta rumah sakit jiwa daerah provinsi jambi setelah dilakukan penerapan standar komunikasi defisit perawatan diri dengan nilai mean (rata-rata) 4,00, dengan standar deviasi 0,725 setelah dilakukan penerapan standar komunikasi defisit perawatan diri, dengan nilai minimum 3 dan maksimum 5

\section{Perbedaan Kemandirian Merawat Diri Pada Pasien Skizofrenia sebelum dan sesudah diberikan penerapan standar komunikasi defisit perawatan diri}

Hasil uji Wilcoxon di dapatkan P-value $=0,001<0,05$ dengan selisih nilai mean 1.00 antara sebelum dilakukan penerapan standar komunikasi defisit perawatan diri dan sesudah dilakukan penerapan standar komunikasi defisit perawatan diri, maka dapat disimpulkan bahwa secara statistik ada Pengaruh Penerapan Standar Komunikasi Defisit Perawatan Diri Terhadap Kemandirian Merawat Diri Pada Pasien Skizofrenia Di Ruang Rawat Inap Delta Di Rumah Sakit Jiwa Daerah Provinsi Jambi yang berarti kemandirian responden mengalami perubahan positif setelah diberikan penerapan standar komunikasi defisit perawatan diri. Adanya penelitian ini membuat responden yang semula tidak mandiri dalam merawat diri setelah dilakukan penerapan standar komunikasi defisit perawatan diri menjadi mandiri dalam merawat diri. Hal ini berarti penerapan standar komunikasi defisit perawatan diri sangat berpengaruh dalam kemandirian merawat diri pada responden skizofrenia.

Sejalan dengan penelitian Pinedendi (2016) dengan judul Pengaruh Penerapan Asuhan Keperawatan Defisit Perawatan Diri Terhadap Kemandirian Personal Hygiene Pada Pasien Di RSJ. Prof. V. L. Ratumbysang Manado Tahun 2016. Instrument penelitian yang digunakan dalam Kemandirianpersonal hygiene diukur denganmenggunakan Indeks Aktivitas Sehari-haridari Barthel (Barthel Index of Activity DailyLiving) dengan penetuan skor 14: mandiri,10-13 Ketergantungan ringan, 7-9Ketergantungan sedang, 4-6 Ketergantunganberat, dan 0-3 Ketergantungan total.Berdasarkan hasilanalisa data uji statistic wilcoxonmenunjukan p-value $=0,046<$ $a ́=0,05$ makaH1 diterima. 
Penelitian Hastuti (2018) dengan judul Pengaruh Pelaksanaan Jadwal Harian Perawatan Diri Terhadap Tingkat Kemandirian Merawat Diri Pada Pasien Skizofrenia Di RSJD DR. RM Soedjarwadi Provinsi Jawa Tengah. Instrument penelitian yang digunakan dalam penelitian ini berupa lembar observasi berisi pengukuran tingkat kemandirian perawatan diri yang berasal dari NANDA dalam Wilkinson (2012) yang penilaiannya telah dimodifikasi dengan lama, komponen perawatan diri yang dinilai adalah kebersihan diri (mandi,oral hygiene, keramas, memotong kuku), berpakaian/ berdandan, makan, eliminasi.Penelitian dilakukan selama 32 hari. Uji statistik didapatkan dengan paired t-test didapatkan nilai $\rho=0,000(\alpha<0,05)$ maka Ha diterima dan Ho ditolak. Nilai mean sebelum pelaksanaan jadwal adalah 15,65 dan setelah dilakukan jadwal nilai mean kemandirian adalah 6,45.

Self-care (perawatan diri) merupakan suatu kontribusi berkelanjutan orang dewasa bagi eksistensinya, kesehatannya dan kesejahteraannya. Self-care ini menggambarkan dan menjelaskan manfaat perawatan diri guna mempertahankan hidup, kesehatan, dan kesejahteraannya. Jika dilakukan secara efektif, upaya perawatan diri dapat memberi kontribusi bagi integritas struktural fungsi dan perkembangan manusia (Budiono, 2015).

Kemandirian adalah suatu sikap yang memungkinkan seseorang untuk bertindak bebas, melakukan sesuatu atas dorongan sendiri untuk kebutuhannya sendiri tanpa bantuan orang lain. Kemandirian adalah sikap yang menghendaki seseorang untuk bertindak bebas. Artinya dapat melakukan sesuatu atas dorongan sendiri sesuai dengan hak dan kewajiban sebagai seorang manusia, yaitu harus mampu menyelesaikan masalahnya sendiri (Hanifah, 2014).

Kebutuhan perawatan diri, menurut Orem, meliputi pemeliharaan udara, air atau cairan, makanan, proses eliminasi normal, keseimbangan antara aktivitas dan istirahat, keseimbangan antara interkasi sosial, pencegahan bahaya bagi kehidupan, fungsi dan kesejahteraan manusia, serta upaya meningkatkan fungsi dan perkembangan individu dalam kelompok sosial sesuai dengan potensi, keterbatasan, dan keinginan untuk normal. Kebutuhan perawatan diri ini sifatnya umum bagi setiap manusia, berkaitan dengan proses kehidupan dan pemeliharaan integritas struktur dan fungsi manusia (Budiono, 2015).

Adapun kemampuan kemandirian merawat diri berdasarkan kriteria hasil Nursing Outcomes Classification dan Intervensi Nursing Interventions Classification dalam Bulechek (2013) dan Moorhead (2013) adalah merawat diri untuk membersihkan tubuhnya sendiri, mengenakkan pakaiannya sendiri, menyiapkan dan memakan makanannya sendiri, dan melakukan aktivitas eliminasi sendiri.

Berdasarkan beberapa penelitian yang telah dialukan, terdapat beberapa perbedaan penelitian, khususnya dalam bentuk intrumen penelitan, prosedur penelitian dan analisa bivariat yang digunakan. Dalam penelitian ini, peneliti menggunakan instrument kemandirian dengan menggunakan Indekz Kemandirian Katz yang sudah dimodifikasi, sedangkan pada penelitian-penelitian sebelumnya Pinedendi (2016) menggunakan Indeks Aktivitas Sehari-haridari Barthel (Barthel Index of Activity Daily Living), penelitian Pinedendi (2016) menggunakan pengukuran tingkat kemandirian perawatan diri yang berasal dari NANDA dalam Wilkinson (2012) yang penilaiannya telah dimodifikasi dengan lama, penelitian Laily, Desy Nur (2014) instrumen penelitian yang digunakan berfokus pada indikator mandi dan berpakaian, berdandan, makan, $\mathrm{BAK} / \mathrm{BAB}$.

Pada prosedur penelitian yang dilakukan sebelum-sebelumnya pun terdapat perbedaan waktu. Pada penelitian 
ini, peneliti menggunakan waktu selama 14 hari, dimulai dari pre-test dilakukan selama 3 hari, treatment dilakukan selama 2 hari perlakuan, 1 hari perlakuan selama 25-30 menit dan post-test dilakukan pada hari berikutnya. Pada penelitian ini, peneliti mengambil sampel sebanyak 20 orang dengan tekhnik purposive sampling, dan sampel yang diambil adalah Pasien dengan diagnosa keperawatan Defisit Perawatan Diri di ruangan rawat inap yang sudah mendapatkan Strategi Pelaksana (SP) 1-4 generalis di ruang rawat inap Delta Rumah Sakit Jiwa Provinsi Jambi Tahun 2019. Dalam penelitian Hastuti (2018) selama 32 hari, penelitian Laily, Desy Nur (2014) selama 22 hari.

Dalam pengolahan data berupa analisa bivariat, peneliti menemukan beberapa perbedaan dengan penelitian sebelumnya. Dalam pengolaha data Analisa bivariat, peneliti menggunakan uji Wilcoxon. Dikarenakan data peneliti tidak berdistribusi normal. Dan ini sejalan dengan penelitian Pinedendi (2016) dengan judul Pengaruh Penerapan Asuhan Keperawatan Defisit Perawatan Diri Terhadap Kemandirian Personal Hygiene Pada Pasien Di RSJ. Prof. V. L. Ratumbysang Manado Tahun 2016.

Pada penelitian ini didapat hasil bahwa penerapan standar komunikasi defisit perawatan berpengaruh dalam meningkatkan kemandirian pada responden skizofrenia dengan diagnosa keperawatan defisit perawatan diri, serta dapat merubah pola hidup responden untuk lebih mandiri dalam kehidupannya guna memenuhi kebutuhan dasar sehari-hari.

\section{SIMPULAN}

Kesimpulan dalam penelitian ini dapat dilihat dari hasil uji Wilcoxon di dapatkan $P$-value $=0,001<0,05$ dengan selisih nilai mean 1.00 antara sebelum dilakukan penerapan standar komunikasi defisit perawatan diri dan sesudah dilakukan penerapan standar komunikasi defisit perawatan diri, maka dapat disimpulkan bahwa secara statistik ada Pengaruh Penerapan Standar Komunikasi Defisit Perawatan Diri Terhadap Kemandirian Merawat Diri Pada Pasien Skizofrenia Di Ruang Rawat Inap Delta Di Rumah Sakit Jiwa Daerah Provinsi Jambi.

\section{SARAN}

Diharapkan untuk peneliti selanjutnya untuk meneliti penerapan standar komunikasi defisit perawatan diri dengan waktu yang lebih lama agar peningkatan penerapan standar komunikasi defisit perawatan diri lebih efektif sehingga kemungkinan pasien untuk mandiri lebih baik.

\section{DAFTAR PUSTAKA}

Ardhiyanti, dkk. 2014. Panduan Lengkap Keterampilan Dasar Kebidanan 1. Yogyakarta : Deepublish.

Arikunto. 2013. Prosedur Penelitian Suatu Pendekatan Praktik. Jakarta : Rineka Cipta

Budiono. 2015. Konsep Dasar Keperawatan. Jakarta : Bumi Medika.

Bulechek, dkk, Gloria M. 2016. Nursing Interventions Classification (NIC). Elsevier Singapore Pte. Ltdp

Davies, Teifion. 2009. ABC Kesehatan Mental. Jakarta : EGC.

Dermawan, Deden. 2013. Keperawatan Jiwa Konsep Dan Kerangka Kerja Asuhan Keperawatan Jiwa. Yogyakarta : Gosyen Publishing.

Direja. 2011. Asuhan Keperawatan Jiwa. Yogyakarta : Nuha Medika.

Ekasari, Mia Fatma, dkk. 2018. Meningkatkan Kualitas Hidup. Malang : Wineka Media.

Festy, Pipit. 2018. Buku Ajar Lansia "Lanjut Usia, Perspektif Dan Masalah”. Surabaya : UM Surabaya Publishing.

Hanifah. 2014. Prosiding Seminar Nasional Pendidikan Dasar "Membedah Anatomi Kurikulum 
2013 Untuk Membangun Masa Depan Pendidikan Yang Lebih Baik. Jawa Barat : UPT Sumedang.

Hastuti. 2018. Pengaruh Pelaksanaan Jadwal Harian Perawatan Diri Terhadap Tingkat Kemandirian Merawat Diri Pada Pasien Skizofrenia Di RSJD DR. RM Soedjarwadi Provinsi Jawa Tengah. Journal Keperawatan (e-Kp). http://scholar.google.co.id/scholar=j urnal+defisit+perawatan+diri+pasie n+jiwaDiakses 12 Desember 2019.

Ibrahim, A. S. 2011. Skizofrenia Spliting Personality. Tangerang: Jelajah Nusa.

Keliat, Budi Anna. 2014. Model Praktik Keperawatan Profesional Jiwa. Jakarta : EGC.

Keliat, dkk. 2019. Keperawatan Kesehatan Jiwa Komunitas CMHN (Basic Course). Jakarta : EGC.

Keliat, dkk. 2019. Asuhan Keperawatan Jiwa. Jakarta: EGC

Laily, Desy Nur. (2014). Pengaruh Aktivitas Mandiri: Personal Hygiene Terhadap Kemandirian Pasien Defisit Perawatan Diri Pada Pasien Gangguan Jiwa di RSJD Dr. Amino Gondohutomo Semarang tahun 2014. Journal Keperawatan (e-Kp). http://scholar.google.co.id/scholar=j urnal+defisit+perawatan+diri+pasie n+jiwaDiakses 12 Desember 2019.

Maramis, Willy F. 2009. Catatan Ilmu Kedokteran Jiwa Edisi 2. Surabaya : Airlangga University Press.

Moorhead, Sue dkk. Nursing Outcomes Classification (NOC). Elsevier Singapore Pte. Ltd .

Muhith, Abdul. 2016. Pendidikan Keperawatan Gerontik. Yogyakarta: Andi Offset

Nurarif, Amin Huda. 2015. Aplikasi Asuhan Keperawan Berdasarkan Diagnosa Medis dan NANDA NICNOC Jilid 3. Jogjakarta : Medi Action.
Pinedendi, dkk. 2016. Pengaruh Penerapan Asuhan Keperawatan Defisit Perawatan Diri Terhadap Kemandirian Personal Hygiene Pada Pasien Di Rsj. Prof. V. L. Ratumbuysang Manado Tahun 2016. Journal Keperawatan (e-Kp). http://scholar.google.co.id/scholar=j urnal+defisit+perawatan+diri+pasie n+jiwaDiakses 28 September 2019.

Riskesdas. 2018. Hasil Riset Kesehatan Dasar Kementrian Kesehatan RI.http://www.depkes.go.id./recourc es/download/general/Hasil\%Riskesd a\%202013.pdf. Diakses 02 Oktober 2019.

RSJ Provinsi Jambi. 2019. Data Jumlah Pasien Skizofrenia Rawat Inap. RSJD : Jambi.

Sovitriana, Rilla. 2019. Dinamika Psikologis Kasus Penderita Skizofrenia. Sidoarjo : Uwais Inspirasi Indonesia.

Susanti, Herni. 2010. Defisit Perawatan diri Pada Klien Skizofrenia: Aplikasi Teori Keperawatan Orem. Jurnal Keperawatan Indonesia Volume 13. http://scholar.google.co.id/scholar=j urnal+defisit+perawatan+diri+pasie n+jiwaDiakses 28 September 2019.

Sutejo. 2010. Keperawatan Kesehatan Jiwa. Yogyakarta : Pustaka Baru Press.

Videbeck, Sheila L. 2015. Buku Ajar Keperawatan Jiwa. Jakarta : EGC.

WHO. 2016. Kesehatan Jiwa Masyarakat.

www.depkes.go.id/articel/print/1610070 0005/peran-keluarga-dukungkesehatan-jiwa-masyarakat.html Diakses 02 Oktober 2019.

Yosep.I. 2010. Buku Ajar Keperawatan Jiwa. Bandung : Refika Aditama.

Yudhantara. 2015. Sinopsis Skizofrenia Untuk Mahasiswa Kedokteran. Malang : UB Pers. 